\title{
Pro Patria Mori: Sacrificing Life in Service of the Political Community
}

\author{
Theo W. A. de Wit
}

\section{$1 \quad$ Introduction}

At Christmas, 1915, five months after the German invasion and occupation of neutral Belgium, Cardinal Mercier, the primate of Belgium, published a pastoral letter entitled Patriotism and Endurance. In this letter, Mercier passionately argued that the Belgians were justified in regarding their patriotism as 'consecrated' and consequently, the German violation of Belgian national sovereignty as a "sacrilegious profanation". The letter specifically sought to respond to a pastoral-theological question, put to Mercier by members of his flock, namely whether or not it is justified to view soldiers falling for a just cause ("which ours clearly is") as martyrs. Mercier's immediate response was 'no', not in the theological sense of the word, for after all, unlike soldiers, the Christian martyr does not resist his executioners. At the same time however, Mercier had little doubt that any soldier who, in avenging violated justice, laid down his life in honor of his fatherland, would be assured of eternal salvation:

The soldier who dies to save his brothers, to protect the hearths and the altars of his country, fulfils the highest form of love. (...) We are justified for hoping for them the immortal crown which encircles the foreheads of the elects. For such is the virtue of an act of perfect love that, of itself alone, it wipes out a whole life of sin. Of a sinner instantly it makes a saint. ${ }^{1}$

A few months later his French counterpart, cardinal Billot, responded with severe disapproval:

To say that the mere fact of dying consciously for the just cause of the Fatherland "suffices to assure salvation" means to substitute the

1 See for the full text of the pastoral letter in English http://www.zum.de/psm/1wk/ww1/ mercier.php3. 
Fatherland for God (...), to forget what God is, what is sin, what is divine forgiveness. ${ }^{2}$

To Billot, positing any political-theological link between God and fatherland, between the forgiving of sins and the imperatives of patriotic duty, was theologically indefensible and should therefore be resisted.

In 1951 the medievalist Ernst Kantorowicz, who was a great authority on medieval political theology, revisited this remarkable and fundamental difference of opinion within the Roman Catholic Church at that dramatic moment in modern European history, in an article entitled Pro Patria Mori. Kantorowicz's historic-systematic reflections in this article point to the conclusion that, during the first half of the twentieth century, the notion of sacrificing one's life in service of the fatherland had fallen into discredit. This conclusion, which I will reformulate as a statement of problem, will be my point of departure (II).

Not long after the First World War however, Carl Schmitt (1888-1985) a controversial, seminal, German jurist and political thinker - would reestablish the notion of laying down one's life in service of the state as central to our political existence, and to the state's sovereignty, in his polemical treatise The Concept of the Political ${ }^{3}$ which was aimed against post-war, liberal Weimar Republic Germany's putting in perspective of state and politics. Schmitt's invocation of Thomas Hobbes in support of his argument however, fails to square with the fact that specifically Hobbes may be regarded as one of the first modern political theorist to attack the notion of the primacy of community over individual (III).

Current political-philosophical and political-theological discussions regarding the continued meaningfulness of pro patria mori may be viewed in the continuum of the initial debate between Mercier/Schmitt on the one hand, and Billot on the other. Recently, the American philosopher of law Paul W. Kahn

2 E. H. Kantorowicz, "Pro Patria Mori in Medieval Political Thought," in Selected Studies (eds Michael Cherniavsky and Ralph E. Giesey; New York: Augustin, 1965), 308-324 (309). See also E. H. Kantorowicz, The King's Two Bodies: A Study in Medieval Political Theology (Princeton NJ: Princeton University Press, 1957), v.3, "Pro patria mori," 232-273.

3 Carl Schmitt, The Concept of the Political, trans. George Schwab (Chicago, London: The University of Chicago Press, 1996). Translation of Carl Schmitt, Der Begriff des Politischen. Text von 1932 mit einem Vorwort und drei Corollarien (Berlin: Duncker \& Humblot, 1963). The first version of the text appeared in 1927 as an article in Archiv für Sozialwissenschaft und Sozialpolitik 58, 1 (1927), 1-33. See also Carl Schmitt, Political Theology. Four Chapters on the Concept of Sovereignty, trans. George Schwab (Chicago: University of Chicago Press, 2005). The common translation of Politische Theologie; vier Kapitel zur Lehre von der Souveränität (Berlin: Duncker \& Humblot, 1921). 
chose to emphatically side with Schmitt. His compatriot, the theologian and ethical theorist Stanley Hauerwas, in following Billot (and theologians such as Karl Barth ${ }^{4}$ ), however appears to harbor grave reserves, specifically regarding the corollary to the willingness to die for one's country, namely the willingness to kill for it (IV).

\section{An Ancient Value, Dissolving Like Smoke}

To Kantorowicz, the cardinals' difference of opinion is cause for launching an historical investigation into the whole notion of pro patria mori. For, as he phrases his consideration:

If two eminent princes of the Church disagree so profoundly on a fundamental matter of life and death, and of life after death, we may be sure that the reasons for such a basic disagreement are to be sought in a distant past and that the whole problem has a long history. ${ }^{5}$

In an exquisitely documented contribution, he then shows that death in service of the community - for patria read here 'city' (polis), and all the city stood for - was first and foremost a cherished ideal of Greek and Roman classical antiquity. In subsequent feudal times, mainly as a result of the growing influence of Christianity, this notion of laying down one's life for the good of the city however gradually lost its emotional and (semi-)religious significance. For, as we may already read in St Augustine, Christians not so much fight and fall for the sake of earthly fame, but rather - as martyrs - for that of the invisible patria aeterna, the heavenly Jerusalem.

Only in the twelfth and thirteenth centuries would the temporal notion of patria (now framed in terms of national territory or kingdom) regain its emotional appeal, and thus, by manner of speaking, return from heaven to earth. A precedent for the contrasting positions of Mercier's politico-theological affirmation and Billot's theological reservations, may be found in a much earlier debate, namely that of whether participation in a Crusade would contribute

4 The Wikipedia article on Hauerwas (accessed January 1, 2015) explicitly mentions Karl Barth as an influence. With regard to Barth's position on the First Word War, see Dieter Schellong, "Jenseits von politischer Theologie und unpolitischer Theologie. Zum Ansatz der Dialektischen Theologie," in Der Fürst dieser Welt. Carl Schmitt und die Folgen (ed. Jacob Taubes; München: Wilhelm Fink Verlag/Verlag Ferdinand Schöningh, 1983), 292-316.

5 E. H. Kantorowicz, "Pro Patria Mori in Medieval Thought," 308 and 309. 
to the crusader's salvation or not. While the Council of Clermont (1095) clearly established that the crusader would be absolved of any unfulfilled churchly penances (for instance prescribed fasting, giving alms, prayers), but not of all sins (remissio peccatorum), in political and churchly practice this distinction was generally ignored. As a result, common understanding held that any crusader who fell in defense of the Holy Land would automatically become a martyr, gaining direct access to paradise.

By the early fifteenth century, at the height of this development towards a sacralization and a greater appreciation of the emotive value of the notion of country (France, Francia Deo sacra, constitutes the paradigm in this regard), some authors were even starting to draw close parallels between the martyr's death (or that of the crusader), and the act of sacrificing one's life in defense of the corpus mysticum of the fatherland - both namely acts rooted in love (caritas).

Kantorowicz concludes that the positions of both Mercier and Billot, each in their own way, find vindication in tradition: While Mercier's pastoral patriotism follows a well-established tradition of ecclesiastical and political thinking, Billot has theological dogma on his side when he admonishes against the 'substitution' of fatherland for God. Of most relevance to us however, is a concluding remark Kantorowicz permits himself at the end of his investigation. This remark is not only indicative of the modesty of this great medievalist, but also betrays a certain dismay when he lets slip that:

It may be left to the reader to figure out all the distortions which the central idea of the corpus mysticum has suffered by its transference to national, party, and racial doctrines in more distant and in most recent times. $^{6}$

Kantorowicz here refers to the examples of the "Tombs of the Martyrs" which the National Socialists erected in Munich in 1932, and to the gigantic banner, proclaiming Chi muore per Italia non muore ${ }^{7}$ draped over the façade of the Milan cathedral as backdrop to the 1937 Christmas memorial service for Fascist Italy's fallen combatants in the Spanish Civil War.

To Kantorowicz, these 'distortions', together with a growing "disenchantment of the world", signal that "the ancient ethical values, miserably abused and exploited in every quarter, are about to dissolve like smoke". Given the "cold efficiency" witnessed during and since the Second World War on the

6 Kantorowicz, "Pro patria mori in medieval Thought," 324.

7 "Whoever die for Italy do not die." 
one hand, and the contemporary individual's fear of falling into the trap of religio-ideological 'illusions' on the other, it would seem the days of the traditional religious and ideological 'superstructure' are numbered. As a result, Kantorowicz suspects that:

Human lives (are) no longer (being) sacrificed but 'liquidated'. We are about to demand a soldier's death without any reconciling emotional equivalent for the lost life. If the soldier's death in action - not to mention the citizen's death in bomb-struck cities - is deprived of any idea encompassing humanitas, be it God or king or patria, it will be deprived also of the ennobling idea of self-sacrifice. It becomes a cold-blooded slaughter or, what is worse, assumes the value and significance of a political traffic accident on a bank holiday. 8

If I were to - for my own purposes in this essay - somewhat reformulate and actualize Kantorowicz's concluding remark from 1951, I would describe the new constellation he points towards, as follows. By instrumentalizing traditional, ancient values (such as that of pro patria mori), the great totalitarian movements of the twentieth century - the century of the "slave revolt of technology" in Walter Benjamin's apt description ${ }^{9}$ - suddenly restored the political relevance of certain theological, eschatological reservations which have been present within Christianity for a long time. Specifically, reservations pertaining to any strong affinity towards, or 'cohesion' with, political-military power. The catastrophic devastation of two world wars have taught Europeans the bitter lessons that nation is best not tied to religion, that churches should refrain from lending their weight to the exaltation - the "praising to heaven" - of dying in war.

But the simultaneous loss of what Kantorowicz indicates as an "idea encompassing humanitas" also points towards a nascent void. Especially during the past two decades, Western politics, both within Europe and abroad, once more seem to hover between a bleak and defensive liberalism (Kantorowicz's "anti-ideological individual") with rational management and a purely formal notion of citizenship on the one hand, and on the other, the longing for a (greater) sense of community, and the reemergence of nationalistic politics. The German journalist Richard Herzinger's book Die Tyrannei des Gemeinsinns

8 Kantorowicz, "Pro Patria Mori in Medieval Thought," 324.

9 W. Benjamin, "Theorien des deutschen Faschismus," in Schriften III (Frankfurt am Main: Suhrkamp, 1972), 238:Jeder kommende Krieg ist zugleich ein Sklavenaufstand der Technik. 
(1997) provides a good example of the first tendency. ${ }^{10}$ In this book, Herzinger bids farewell to the Gemeinsinn (community spirit) and its "sacrificial logic", instead making a strong plea for the "egoistical society". The second tendency may be observed in the reemergence of what many see as that kind of populist, nationalist sacrificial politics which Erich Voegelin in 1939 had termed "political religion" - that is, of the sacralization of collective identities such as state, nation and race. ${ }^{11}$ As we shall see below, these contradictory trends were already apparent to Carl Schmitt's writings in the 1930s.

3 Carl Schmitt: Killing and Dying for "One's Own"

At first glance, Schmitt provides a Hegelian ${ }^{12}$ 'statist' defense of the notion of sacrificing one's life for the political community - this already during the early 1920 in Weimar Germany, and most explicitly in his renowned The Concept of the Political (1927; 1932). In the central fifth paragraph of this treatise on the political (Das Politische), entitled "decision concerning war and enemy", one reads for instance:

The state as the decisive political entity possesses an enormous power: The possibility of waging war and thereby publicly disposing of the lives of men. The ius belli contains such a disposition. It implies a double possibility: The right to demand from its own members the readiness to die (Todesbereitschaft) and unhesitatingly to kill enemies

10 Richard Herzinger, Die Tyrannei des Gemeinsinns. Ein Bekenntnis zur egoistischen Gesellschaft (Berlin: Rowohlt, 1997), especially "Lob des Egoismus" (80-91) and "Verlocherungen der Transzendenz oder Opfer und Interesse" (183-211). Particularly the German 'Opferkult' (193) gets Herzinger hot under the collar: Gefeiert werden in Deutschland die Märtyrer, die Aushalter auf verlorener Posten, die immer an ihrem Platz stehen und nicht anders können. Die Linke verehrt die Messiasgestalten der Ausgebeutenen und Entrechteten, die sich schlachten liessen. Here Thomas Münzer, Rosa Luxemburg and Che Quevara are the heroes. Die Rechte verehrt dagegen den Frontsoldaten, der, von Führung und Heimat verlassen, tapfer seine Pflicht tat bis zum bitteren Ende, von Verdun bis Stalingrad. In brief: "Opfern für die Zukunft, ausharren für die Ewigkeit” (86-87).

11 E. Voegelin, Die Politischen Religionen (Stockholm: Bermann-Fischer Verlag, 1939). See also John Gray's actualization thereof, Black Mass. Apocalyptic Religion and the Death of Utopia (London: Penguin, 2007).

12 For Hegel's justification of sacrifice in service of the nation, see Peter Jonkers, "Justifying Sacrifice," Neue Zeitschrift für systematische Theologie und Religionsphilosophie 50 (2008): $313-329$. 
(Tötungsbereitschaft). (...) By virtue of this power over the physical life of men, the political community transcends all other associations or societies. ${ }^{13}$

The state particularly also 'transcends' the "individualistic principles of a liberal economic order". In an essentially individualist liberal society however, the individual himself decides which causes are personally worth dying for that is, as "a thoroughly private matter, decided upon freely". ${ }^{14}$ According to this principle, "sacrificing one's own life" (sein Leben opfern), in the traditional sense of pro patria mori, cannot be justified on any grounds:

War, the readiness of combatants to die, the physical killing of human beings who belong on the side of the enemy - all this has no normative meaning, but an existential meaning only, particularly in a real combat situation with a real enemy. There exist no rational purpose, no norm no matter how true, no program no matter how exemplary, no social ideal no matter how beautiful, no legitimacy nor legality which could justify men in killing each other for this reason. ${ }^{15}$

Schmitt also identifies what is actually at stake in this extreme 'existential' situation, when the sacrifice of the individual's life is demanded. What is being defended, is the own, "one's own form of existence" (Die eigene Art Existenz). ${ }^{16}$

But why does Schmitt, writing in the context of the young Weimar democracy, place such emphasis on precisely this unique position of the state - the sacrifice of the lives of its citizens and their willingness to kill? Because the state's sovereignty and 'transcendence' have ceased to be self-evident, and - in Schmitt's own diagnosis - may even be under radical threat. This is already evident from the very first, somewhat cryptic sentence of his treatise: "The concept of the state presupposes the concept of the political". ${ }^{17}$ With this

\footnotetext{
13 Schmitt, Concept, 46 and 47.

14 Schmitt, Concept, 48.

15 Schmitt, Concept, 48-49.

16 Schmitt, Concept, 27.

17 Schmitt, Concept, 19. Also the sentence from the Political Theology which brought Schmitt enduring fame and notoriety (5 and 35: "Sovereign is he who decides on the Exception") contains this message - after all, the sovereign does not necessarily, per se, have to be the state. According to Wolfgang Palaver, the first sentence of The Concept of the Political in its reference to the Polis - already indicates the 'Greek' and 'mythical' (not biblical) roots of Schmitt's concept of the political, as Schmitt himself recognizes in a letter to Christian Meier from 29 mai 1968. See Palaver, Die mythischen Quellen des Politischen.
} 
Schmitt directly distances himself from traditional German political theory, in which politics are identified with state, politisch coincides with staatlich. ${ }^{18}$

Schmitt takes his point of departure in establishing that the state, as a result of the emergence of a new type of political subject, is in the process of losing its monopoly on politics. To Schmitt, the fundamental political-philosophical question with regard to the proper or specific of the political (Das Politische) therefore needs to be raised anew. Schmitt's response is by way of a conceptual definition, expressed in the form of a criterion: "The specific political distinction to which political actions and motives can be reduced, is that between friend and enemy". ${ }^{19}$ Ultimately, albeit to varying degrees, all relations which may rightly be termed 'politics' refer to "the ever present possibility of combat", in extreme instances, of civil war, or, once political unity (for instance the state) had been established, the possibility of an external, foreign enemy. To varying degrees: Properly viewed, the political constitutes no own domain or territory ('politics', as we are in the habit of saying) of its own; it denotes "the utmost degree of intensity of a union or separation, of an association or dissociation", and may be fed from a number of sources or domains. ${ }^{20}$ Religious, economic or ethnic differences within a society may become politicized to the point of a confrontation ad mortem. To Schmitt, concepts such as friend, enemy and struggle all ultimately refer to the actual possibility of the "physical act of killing".

\subsection{Reflection on the Independence of the Political from the State}

Two aspects of Schmitt's thinking this far deserve closer attention within the context of my own investigation into the fate and legitimacy of the notion of pro patria mori.

Firstly, only once the political ceases to indicate an independent domain, once it comes to indicate the "intensity of a union or separation", can one truly speak of the emancipation of the political from the state. And because we know that for Schmitt the highest intensity is achieved in the willingness to kill or be

Carl Schmitts Freund-Feind-Theorie (Stuttgart, Berlin, Köln: Kohlhammer, 1998), 35; and Wolfgang Palaver, "A Girardian Reading of Schmitt's 'Political Theology," Telos. A Quarterly Journal of Critical Thought, 93 (1992): 43-68. The rest of my analysis will confirm his thesis. In this regard, see Christoph Schönberger, "Der Begriff des Staates in Begriff des Politischen," in Carl Schmitt. Der Begriff des Politischen. Ein kooperativer Kommentar (ed. Reinhard Mehring; Berlin: Akademie Verlag, 2003), 21-45.

19 Schmitt, Concept, 26.

20 Schmitt, Concept, 26. 
killed, this emancipation potentially also holds a detachment of mortal sacrifice from the sphere of the national state.

What Schmitt observed in his own time, was that other political subjects were now vying with the state in demanding the ultimate sacrifice: Warring civil parties, partisans, guerillas, revolutionary classes and religions, terrorist groupings, etc. ${ }^{21}$ In this regard, Schmitt's theorizing anticipated our own world, where sacrificial willingness has long since become detached from state. Schmitt himself, however has a clear nostalgia for the 'transcendental' state which protects society "from above", and in exchange demands obedience from its citizens, and, in war, the supreme sacrifice. Schmitt therefore views these new political subjects as, in the first instance, competitors of the state, as proto-states. Into the 1930 s he would keep hoping for a new, strong state, one able to harness and transcend social discord and conflict potential - thus his notorious backing of Hitler and the Nazi regime. At this point, the theory of René Girard on the 'scapegoat-mechanism' can be applied on Schmitt's theory of the Political, as - among others - Wolfgang Palaver did: "The civil War, the enmity within the State, is superseded by the transposition of enmity to an enemy outside". 22

Nevertheless, already in the late 1920s, Schmitt clearly saw and described the political reality of new, non-state, political subjects, equally demanding from their members a willingness to be killed, or to kill - potentially also of non-combatants. And with this, a new type of war and a new image of sacrifice appears on the horizon. 'Symmetrical' warfare, between sovereign states of equal rank in which regular combatants lay down their lives, becomes supplanted by the 'asymmetrical' warfare of partisans, guerillas and terrorist groups, internally demanding total engagement; externally, the willingness to sacrifice the lives of innocent civilians in pursuit of a grand ideal. ${ }^{23}$

Attentive readers of Schmitt, such as Leo Strauss, Helmut Kuhn and Heinrich Meier - the first two already when the second version of Schmitt's treatise appeared in 1932 - have noted that the roots of Schmitt's emphatic

21 See also Carl Schmitt, Theorie des Partisanen, Zwischenbemerkung zum Begriff des Politischen (Berlin: Duncker \& Humblot, 1963).

22 Wolffgang Palaver, Die Mythischen Quellen des Politischen, 36. See also Paul Dumouchel, Le sacrifice inutile. Essai sur la violence politique, Paris: Flammarion, 2011, especially 118-124 about Schmitt, and 134-138 about Girard: 'Cette structuration de l'espace de solidarité/hostilité vise à protéger le groupe contre la violence' (134).

23 With regard to this development away from symmetrical towards asymmetrical warfare, see: H. Münkler, "Symmetrische und asymmetrische Kriege," in Merkur 58. Jg. Heft 8, (2004), 649-659; H. Münkler, Die neuen Kriege (Reinbek bei Hamburg: Rowohlt, 2002), especially $\mathrm{Ch}_{5}$, „Der internationale Terrorismus, “ $175^{-207 .}$ 
defense of Das Politische, as a realm of diverse human associations laying claim to the ultimate sacrifice, are essentially moral, even theological or mythical in nature. ${ }^{24}$ Schmitt does not believe in a post-political world in which political struggle and the existential significance of sacrificial willingness have become supplanted by straightforward economic competition, eternal discussion, an unquenchable quest for entertainment and wanton consumerism - in other words, the liberal Utopia, "The End of History" which Fukuyama optimistically hailed following the downfall of communism. ${ }^{25}$ The political and its 'intensity' - and with that, (self)sacrifice - are however unavoidable, says Schmitt. On this point, he indeed pays resemblance to many of today's antiliberal - both religious or conservative as well as revolutionary - movements, shunning neither the sacrifice of self or (innocent) others in the name of a fictional patria or Heimat, projected onto the past or future.

\subsection{The Demise of Self-Sacrifice: Thomas Hobbes' 'Individualistic' Liberalism}

We have now arrived at the second aspect of interest to my investigation. As we saw, to Schmitt the risk of death constitutes the very reason for the existence of politics, its raison d'être. It is the existential risk - never completely predictable, never to be decided by a previously determined norm - which distinguishes the political community from all other human associations and affiliations: Only a political community or grouping can ask of its citizens, casu quo adherents, to kill or to be killed on its behalf.

It is therefore somewhat odd that Schmitt - in this treatise, but also in some of his other works - would make frequent appeal to the work of the seventeenth

24 Heinrich Meier, Carl Schmitt, Leo Strauss und „Der Begriff des Politischen,"Zu einer Dialog unter Abwesenden, (Stuttgart: Metzler, 1988); Theo W. A. de Wit, De onontkoombaarheid van de politiek. De soevereine vijand in de politieke filosofie van Carl Schmitt (Nijmegen: Pomppers, 1992). Wolfgang Palaver argued - convincingly, I think - against Heinrich Meier that Schmitts defense of the Political has 'mythical' (Greek, Roman and 'heidenchristliche'), not theological-eschatological roots. Papaver, 'Die mythischen Quellen', 4: "Die mythische bzw. religiös-rituellen Quellen des Begriffs des Politischen," 35-50.

25 Leo Strauss, "Notes on Carl Schmitt, The Concept of the Political (1932)," in Heinrich Meier, Carl Schmitt, 97-125; Helmuth Kuhn, "Besprechung zu: Carl Schmitt, Der Begriff des Politischen," Kant-Studien 38 (1933): 190-196. With regard to Fukuyama's utopia of the 'end of history', Francis Fukuyama, The End of History and the last Man, (New York: Free Press, 1992), and for my commentary, Theo W. A. de Wit, "De lompenverzamelaar en het libretto van de geschiedenis," Armada 45 (2006): 27-42. 
century thinker Thomas Hobbes. ${ }^{26}$ Certainly, also to Hobbes the possibility of death constituted the fundamental raison d'être of politics - and no longer, as was the case for a whole classical tradition stretching back to Aristotle, the pursuit of the good life. On closer inspection however, precisely here also lies an important distinction between our two thinkers. To Hobbes, the violent death of the individual in the "state of nature" (in Hobbes' construct of state, a fictitious status in which each person is law unto itself) is the very epitome of evil. It is the fear of death which drives mortal human beings towards a "civil state" and towards the state - a supreme, sovereign entity which establishes the rule of law, and is capable of offering effective protection. Guaranteeing the self-preservation of the individual therefore also constitutes the primary function of the state. Therefore, to Hobbes, the duty of obedience only holds as good as the guarantee of protection.

Seen in terms of Hobbes' construct of state, where individual self-preservation is at the very heart of the political covenant, Schmitt's political defense of the individual's willingness to kill or be killed on behalf of the collective existence is therefore plainly an anomaly. After all, as Hobbes puts it:

Obligation of Subjects to the Sovereign, is understood to last as long, and no longer, than the power lasteth, by which he is able to protect them. For the right men have by nature to protect themselves, when none else can protect them, can by no Covenant be relinquished. ${ }^{27}$

Some have noted that with this statement, Hobbes' entire construct of state degenerates into an "absurdity". For, when it comes to the crunch, when the sovereign really needs the utmost support of its subjects (that is, when the state itself is in danger) "they are admitted to be free to withdraw their support if in their judgment he is no longer clearly able to protect them". ${ }^{28}$

At this point we need to revisit one of the key building blocks of Hobbes' construct of state. Hobbes starts out by fixing the citizen's most important motives for choosing for the state - in other words, for a peaceful existence -

26 See also Der Begriff des Politischen, and especially the reference to Hobbes (121-123) unjustly lacking from the English translation version. See also Carl Schmitt, Der Leviathan in der Staatslehre des Thomas Hobbes. Sinn und Fehlschlag eines politischen Symbols (Hamburg: Hanseatische Verlagsanstalt, 1938).

27 Thomas Hobbes, Leviathan, or the matter, forme \& power of a commonwealth ecclesiastical and civil (ed. Macpherson; London: Pelican Books, 1968), 272.

28 C. B. Macpherson, 'Introduction' in Hobbes, Leviathan, 62. 
in a series of moral prescriptions, or laws of nature. ${ }^{29}$ Together, these constitute the conscience of the common, average (obviously still Christian) citizen. By transforming these moral prescriptions into positive laws, the state ensures the conditions necessary for their observance - something which was impossible in the "state of nature". In this scheme however, military service, courage and dare ("the Contempt of Wounds, and violent Death") ${ }^{30}$ have no obvious place. Hobbes therefore also explicitly denies the status of courage as a virtue. ${ }^{31}$

Therefore, in Hobbes' theory of state, military virtues and the love of one's country unto death, suddenly become problematic - a firm departure from tradition, which, in Kantorowicz's reconstruction, stretches back to GrecoRoman times. On the contrary, says Hobbes, it is precisely the state's duty to ensure the moral innocence of its subjects, to prevent them from becoming "guilty of warre" 32 - as would otherwise likely have been the case in a state of nature. Herewith the modern separation of politics and morality: Simply put, the norms of civilian life do not apply to the state and its raison d'etat, such being intimately related to matters of aggression and enmity. The citizen is protected and simultaneously screened off from evil by the state: Ideally, the conduct of war is not the business of the common citizen. Ideally, for the weakness of the Hobbesian state becomes apparent as soon as the state has to appeal to its citizens in times of peril, in other words, when the protector itself becomes in need of protection.

In agreement with Leo Strauss, this difference between Hobbes and Schmitt may be encapsulated as follows: While Hobbes, living in an illiberal world, may be regarded as the founder of liberalism and its attendant ideal of peaceful civilization, human rights and a humanity underway towards a single, united "partnership in consumption and production", Schmitt, living in a liberal world, sees his task in undertaking a critique of liberalism by pointing out the overlooked lasting 'intensity' of the political. ${ }^{33}$

\footnotetext{
29 Hobbes, Leviathan, Chapter 14 and 15.

30 Hobbes, Leviathan, 717. See Th. W. A. de Wit \& Marin Terpstra, "Afschrikking en zelfopoffering. Thomas Hobbes en het nucleaire tijdperk," Krisis 29, 1987, 27-46.

31 Leo Strauss reminds us of this in his discussion of Schmitt's treatise on the political, "Notes," 91.

32 That is at the core of the famous chapter 13 of the Leviathan, concerning the "Natural Condition of Mankind," Leviathan, 183-188.

Strauss, Notes, 92-93.
} 


\section{$4 \quad$ The Current Divide: The Sniper and the Terrorist}

Could the Hobbesian ideal of a peaceful life without (self)sacrifice - which Hobbes himself ultimately failed to convincingly conceptualize ${ }^{34}$ - nevertheless still be realized? In the modern history of the right to self-preservation, the factual response to this question has been to re-conceptualize warfare as the ever-diminishing physical deployment of citizens - war which has therefore become more disembodied, abstract, technical and devastating. A good account of the Rationalization of Slaughter in modern times is given by the British historian Daniel Pick in his book War Machine. ${ }^{35}$ The threat of nuclear holocaust embodies the ultimate consequence of this development. Nuclear weapons, in common with all other weapons which raise the threat of catastrophic war to unimaginable proportions, are the paradoxical outcome of a culture which elevates self-preservation to an absolute norm, while at the same time refusing to renounce the protection of state or world order against external threats. The impotent, pyrrhic, threat of the sacrificial pyre (Holocaust) is therefore in fact the corollary of our cultural repugnance towards any resolution of conflict by violent means, and especially towards the notion of self-sacrifice - something which countless people today would no doubt view as nothing short of insanity. By the way, Hobbes also brilliantly anticipated this development when voicing his deep skepticism of Christian ambitions of martyrdom and of those who come into conflict with the civil authorities as a result of their homespun evangelical doctrines. ${ }^{36}$

During the Cold War, this doctrine of deterrence would present the world with a huge dilemma: Absolute peace between the two superpowers, or global annihilation. In our own time, the dilemma has become whether or not it would be equitable to effectively freeze existing global political-military power relations in order to prevent the proliferation of nuclear weapons (in for instance Iran).

34 At the end of Leviathan, in the "Review and Conclusion," Hobbes suddenly comes up with a new 'last' natural law, namely: "That every man is bound by Nature, as much as in him lieth, to protect in Warre, the Authority, by which he is himself protected in time of Peace." (Leviathan, 718-719). With regard to this inconsistency, see De Wit \& Terpstra, "Afschrikking en zelfopoffering," 27-35.

35 Daniel Pick, War Machine. The rationalisation of slaughter in the Modern Age (New Haven \& London: Yale University Press, 1993).

36 See especially Ch. 42 of his Leviathan, 'Of Power Ecclesiastical', 521-6o9. 
But it is particularly the following divide which nowadays determines the status and deployment of the notion of ultimate sacrifice in politics. The liberal, secular and democratically governed part of the world, hardly longer able to justify the notion of community-spirited self-sacrifice to itself, is increasingly confronted by that part of humanity which regards peaceful civilian existence without a hereafter simply a material and spiritual impossibility: Irredeemable warmongers, mercenaries and irregular terror groups of all ilk; but also poor and oppressed masses, receptive to the religious compensations to poverty and defeat offered by their leaders.

These two worlds have become embroiled in a number of political-military conflicts; none ever boding well, for all are morally utterly questionable. The moral weakness of a 'Hobbesian', post-heroic (especially European) world, essentially stripped of the notion of ultimate sacrifice, lies in the way she seeks to conduct her wars (nowadays often termed punitive strikes, peacekeeping missions and pacifications): That is, killing, while shunning the risk of getting killed. The American political philosopher Michael Walzer thus refers to Albert Camus ("You can't kill unless you are prepared to die") in his criticism of Us intervention in Kosovo during the late 199os. By mainly relying on superior air power and guided missile strikes, us strategy essentially entailed the massive deployment of firepower against Serb forces - with inevitable, significant Serbian "collateral damage" - while keeping the risk of its own losses to a bare minimum. ${ }^{37}$ The soldier has now essentially become a sniper - executing the enemy from a distance. The same is true for the introduction of drones by states in their "war on terror": Sacrificing lives in the name of 'our' security is getting identical to 'liquidation' (as Kantorowicz suspected)

The moral poverty of the second world, one until recently symbolized by Osama bin Laden, lies in using poor and humiliated groups and masses for its paradise's insatiable appetite for martyred lives; while its 'victories' purely reside in a perverse quest to take as many opponent lives as possible. Punishment and revenge better describe their practices than the older European concepts of war, ${ }^{38}$ For example, 'revenge' was the explicit motive of the terrorists who liquidated a great part of the editorial staff of the French journal Charlie Hebdo in January, 1915.

In a spiritual universe based on the pursuit of the earthly happiness of the greatest number of individuals - as Europe had largely become - it is becoming

37 Michael Walzer, Arguing about War (New Haven \& London: Yale University Press, 2004), 101.

38 See Marcel Hénaff, "Terror und Rache. Politische Gewalt, Gegenseitigkeit, Gerechtigkeit zehn Jahre danach," Lettre international 94, 2011, 11-15. 
increasingly difficult to ascribe any continued meaning to the notion of mortal self-sacrifice. "These guys have chosen for it", would be a typical (but not uniquely) Dutch response to such casualties as may be suffered in, for instance, Afghanistan - a response indicative that, to many, the notion of supraindividual duty has become alien, incomprehensible even. After all, is not the state - or political community - merely an administrative device in service of its citizens? Now who would want to lay down their lives for the inland revenue service anyway? The classical pro patria mori is reframed and reduced to a jobrisk, and falling in Afghanistan now becomes an occupational hazard rather than a matter of mortal self-sacrifice. And this is precisely what Kantorowicz had in mind when talking of soldiers dying in action "without any reconciling emotional equivalent".

Not infrequently, their opponents in the War on Terror invoke the exact mirror image of this scenario. Here the martyr's death is elevated to the pinnacle of human endeavor, and becomes the ultimate manifestation of the political or religious community and its triumphing sovereignty. Thus these two worlds hold one another in a curious and often deadly embrace. At the same time, we have all become inhabitants of a perverse moral universe: Suicidal dying in order to inflict punishment (religiously sanctioned violence), or killing from a safe distance (the war of calculating citizens).

\subsection{Paul Kahn: Sovereignty and Sacrifice}

In conclusion, let us turn to two contemporary American voices which are clearly recognizable as a continuation of the debate between Mercier/Schmitt and Billot, bearing in mind that Hobbes' plea for peace appears to indicate greater affinity with the eschatological reservations of modern theology than Schmitt's sacrificial concept of sovereignty. In Political Theology, a recent study whose very title bears homage to Carl Schmitt, Paul Kahn, author of a number of works on jurisprudence, demonstrates that, in the United States, the concept of state sovereignty continues to remain premised on the notion of patriotic self-sacrifice. Kahn presents a phenomenology of the political which seeks to identify and describe "the presence of the sacred, wherever it appears". ${ }^{39}$ He presents his study as an actualizing interpretation of Schmitt's Politische Theologie (1921), but under the banner of the discipline of 'political theology' he

39 Paul Kahn, Political Theology. Four new Chapters on the Concept of Sovereignty (New York: Columbia University Press, 2011), 25 and 121. Kahn's title only adds the word 'new' to Schmitt's original, Politische Theologie. Vier Kapitel zur Lehre von der Souveränität. (see note 9). From the same author, see also Sacred Violence: Torture, Terror and Sovereignty (Ann Arbor, Michigan: University of Michigan Press, 2008). 
also provides a fairly original description (without any normative intentions) of specifically the American social imaginary of the political, in which he also regularly distances himself from Schmitt's ideological anti-liberalism.

According to the central thesis of his book, a political community is not simply a contractually assented rational entity, governed by the rule of law. The modern American state, forged in revolution, is a unity of identity and law, exception and norm, faith and reason, love and justice, sovereignty and constitution - in short, of reason and an existential will rooted in the revolutionary past. What the political imagery of such a community looks like and not the part played by religious faith - is what is of relevance to a phenomenological and genealogical investigation into the "political theology" of such a political entity. In this regard, Kahn convincingly shows that, in terms of the United States' political self-conception, (national) sovereignty continues to play a key role. Only in light of this notion of sovereignty can one make sense of American's (in)famous 'exceptionalism' - the reluctance to join international human rights conventions and transnational courts - and other manifestations of national self-assurance such as the Pledge of Allegiance, the iconography of the flag, and the memorialization of citizen sacrifice. ${ }^{40}$ The fact that the us president is always trailed by an officer with the nuclear strike codes on hand is further testimony to the fact that Schmitt's famous definition of sovereignty, as he who "decides on the state of exception (Ausnamezustand)" is no mere dead letter in the United States of today. These are all matters largely neglected by dominant liberal theory (Kahn regularly refers to John Rawls in this regard).

We may term Kahn's central thesis Schmittian, for also Schmitt believes that a world which still holds potential enemies cannot be completely governed by law alone, and that the state ought to keep a firm grip on the free exercise of 'exceptional' decisions - precisely in defense of the own way of life and the rule of law, including the possibility of demanding mortal self-sacrifice. Kahn also sees a political-theological continuity with the medieval doctrine of "the two bodies of the king" (one mortal, the other immortal), and the 'transfer' of this sovereignty to the revolutionary concept of national sovereignty. ${ }^{41}$ Just like the king's coronation endowed him with sacred status, the revolution forged the (American) nation into a trans-generational, 'eternal' subject. The revolution had enduringly recast (American) history as the progress towards national sovereignty, while the revolution's 'truths' remain at

\footnotetext{
40 Kahn, Political Theology, 8-17 and 2.

41 Concerning this doctrine, see Kantorowicz's famous book (note 1).
} 
the heart of its citizens' allegiance - to the point of being willing to make the supreme sacrifice.

\subsection{Hauerwas: The Sacrifice of the Unwillingness to Kill}

As remarked, Kahn has no normative intentions, even though he clearly has a corrective of liberal political theorizing in mind - which, in his view, is as inclined as European politics to disregard the existential dimension (i.e. of will) from politics, then only to be surprised by its sudden reappearances. Rightly so, for as I have already mentioned, also Europe is experiencing the reemergence of nationalist impulses, and of emotionally charged issues around collective identity.

It would seem that his compatriot, the well-known theologian and ethical theorist Stanley Hauerwas, author of a number of studies on the ethics of war, not so much wants to challenge Kahn's phenomenology, as insist on a normative and theological evaluation of the American social imaginary of the political. Thus, Hauerwas calls in question the Christian-theological legitimacy of Kahns political theology, as did - as we saw - Wolfgang Palaver in the case of Schmitt. In 2009, Hauerwas published an essay on the sacrificial aspect of war. ${ }^{42}$ His empirical thesis, essentially not entirely dissimilar from Kahn's, has two aspects. War - with also Hauerwas in the first instance thinking of his own political community's numerous wars - not only demands the supreme sacrifice of soldier's lives, war by nature is a "sacrificial system". War has a unique "moral power", that "war creates its own justification".43

War gives purpose and meaning to the lives of many, across generations. It also enables the transformation of common history into a coherent patriotic narrative in which the sides of good and bad, 'us' and 'them', are clearly defined. War also teaches us many valuable moral lessons: That meaning is more important than happiness, that self-interest is less important than nobleminded sacrificial willingness, that hardiness and chivalry are important virtues, and in general, that there are more important issues than our trivial daily concerns. And, while not often admitted, war even has a certain aesthetic dimension to it. As many first-hand accounts testify, the spectacle of war can be

42 Stanley Hauerwas, "Sacrificing the Sacrifices of War," in Religion and Politics of Peace and Conflict (eds Linda Hogan and Dylan Lee Lehrke; Princeton: Princeton Theological Monograph, 2009), 83-104. Also note that the article is also included in Hauerwas' most recent book, War and the American Difference: Theological Reflections on violence and National Identity (Michigan: Baker Academic, 2011).

Hauerwas, "Sacrificing," 86 and 93. 
a captivating affair, powerfully blending destruction with an aesthetic pleasure "beyond good and evil". And many a soldier has experienced that ecstatically intense degree of camaraderie, where combat essentially becomes a matter of killing or dying for one's comrades, one's 'buddies'. And in conclusion, says Hauerwas, war manages to "to close the gap between piety - which required self-abnegation and self-sacrifice - and violence", by for instance establishing the death of Christ and those of the fallen within the same continuum. ${ }^{44}$ As we have seen, this was what Cardinal Billot had protested against in 1915 .

Apart from conveying a well-defined ethos and political-religious narrative, war is self-justifying in another way. The state sending its troops to war is forced to provide some kind of meaning to the deaths of its fallen. For this reason, politicians would hardly if ever concede that a particular war mission had been a mistake or a failure, and rather tend to portray defeats as victories. To concede to error would after all mean to betray those lives sacrificed. Thus war has become self-justifying, almost impossible to criticize. For historical truth needs to be adapted to the unchangeable facts of dying and the death of the enemy.

The second part of Hauerwas' thesis concerns the killing of the enemy. For in war, of soldiers is required not only "the willingness to be killed", but also "as its dark side, the sacrifice of our unwillingness to kill". In evidence, he quotes a number of empirical studies which indicate that killing not only leaves most soldiers with deep emotional wounds, but that it also "creates a world of silence, isolating those who have killed".45 Therefore, we may say that "no sacrifice is more dramatic than the sacrifice of those sent to war, that is, the sacrifice of their unwillingness to kill", and that possibly even greater cruelty lurks in the expectation that those who have killed in action, would simply slip back into the 'normality' of civilian life when returned home. ${ }^{46}$

In terms of delineating his own position with regard to the above empirical thesis, the theologian Hauerwas stands closest to Cardinal Billot's eschatological reserve. As members of the body of the Civitas Dei (Hauerwas explicitly refers to St Augustine), the Christian cannot identify himself with an (American) patriotism which - as we have seen in Kahn - turns the nation into a 'religion', worthy of killing and dying for. After all, "in the cross of Christ, the Father has forever ended our attempts to sacrifice to God in terms set by

44 Hauerwas, "Sacrificing," 89. Hauerwas here leans on Allen Frantzen's Bloody Good: Chivalry, Sacrifice, and the Great War (Chicago: University of Chicago Press, 2004).

45 Hauerwas, "Sacrificing," 94 and 95. (Italics are mine).

46 Hauerwas, "Sacrificing," 100. 
the city of man". Translated into secular political philosophical terms, this means "that the World no longer needs to make sacrifices for tribe or state, or even humanity". ${ }^{47}$ Hauerwas here recalls the statement which brought him to theological fame, namely that "the first task of the church is not to make the world more just, but to make the world the world". 48 Thus, no sacralization of war and its sacrificial practices, and skepticism towards all unions precipitated by the specter of war - in other words, a political-theological task of demythologizing.

Hauerwas' affinity to Hobbes as an ethical theorist and to the Hobbesian appeal to the laws of nature and the basic dictates of reason is only at first glance. According to Hauerwas, there is "no more basic natural law than the prohibition against killing". ${ }^{9}$ Also to Hobbes "to seek peace, and follow it" constitutes the first and fundamental law of nature. ${ }^{50}$ But Hauerwas finds the consequence of the Hobbesian world described above (that is, the liberal striving for security while shunning the risk of self-sacrifice), difficult to accept, as may been seen in the following quote:

"I think, that Christians must insist that what is true is not what a society thinks is worth killing for, but rather that for which they think is worth dying." To Hauerwas, we were "created to be at peace with one another and God (...) created to be in communion with one another".51

Faced with the choice of having to kill or be killed, his answer would be rather martyr than murderer, a conviction rooted as much in Christianity as in Socratic tradition. Hobbes however no longer believes in the inherent telos of communion, thus immediately qualifying his newly formulated first law of nature with "and when he cannot contain it (i.e. peace), that he may seek, and use, all helps, and advantages of Warre". ${ }^{52}$ Within the rhetoric of Leviathan, this qualification sought to make acceptable the sovereign's monopoly on violence, for only then could moral prescriptions become practice, and the Christian really can follow his conscience. As mentioned, here starts the Hobbesian separation of morals and politics - a historic development which has ended up in

\footnotetext{
47 Hauerwas, "Sacrificing," 102.

48 Hauerwas, "Sacrificing," 101.

49 Hauerwas, "Sacrificing," 103.

$5^{\circ} \quad$ Hobbes, Leviathan, 190.

$5^{1}$ Hauerwas, "Sacrificing," 102-103.

52 Hobbes, Leviathan, 190.
} 
a strategy of "killing without risk", and which, to a theologian such is Hauerwas, is completely unacceptable.

\section{Conclusion}

So what conclusion can we draw with regard to the fate of the notion of pro patria mori, with regard to its legitimacy? Kantorowicz's diagnosis of the abuse of this ancient value in modern times has not managed to completely discredit it, as is evident from the work of influential authors like Schmitt and Kahn. The actuality of the notion of self-sacrifice is perhaps most apparent in the Arab world, where many are prepared to give their lives for a new future and true national sovereignty, rooted in the people. These revolutions illustrate an old insight, namely that peace by itself can never be the highest objective, for peace is not always just, and in some cases nothing but a cynical euphemism for decades of repression.

In my view, modern theology has rightly distanced itself from the 'nationalist' notion of sacrifice. The core message at the heart of the eschatological reserve is the following: We ourselves cannot determine whether 'our' wars are just in the eyes of God or not. Therefore, not infrequently nations have to wait a long time before knowing for sure whether a revolution had been a 'felicitous' one or not - also here there is no divine sanction. The Hobbesian legacy of making absolute self-preservation has led to nuclear stalemate, and for some, to a pacifistic criminalization of war - the latter not necessarily pursued by peaceful means. The hunt is now open on the last remaining warmongers (currently of course termed 'terrorists') in a war on war. And here I think we need to support Albert Camus: It is better to run the risk of an honorable and chivalrous death, than to claim the moral high ground without being prepared to risk one's life for it. Schmitt also thinks back nostalgically to the chivalry of the duel between sovereigns - 'classic' warfare - but at the same time diagnoses the rise of asymmetrical forms of struggle and terror, where chivalry is far away. Confronted with the threat of civil war in Weimar Germany he gave way to the temptation, to forge national homogeneity through an external enemy and trough scapegoating. Wolfgang Palaver rightly let Schmitt's attitude correct by F. M. Dostoyevsky, who in The Brothers Karamazov defends the position that:

The rejection of sacrifice and the devotion to universal divine love depend on each other. Only if human beings are ready to give up their lives for each other, only if they accept that they are responsible for the whole 
world and all the sins of human beings, is it possible to avoid scapegoating others. ${ }^{53}$

Thus, the Christian attitude rejects sacrifice and accepts self-sacrifice as a possible consequence of love. Following Jesus' saying about the grain of corn in John, 12:24, which was the motto of his novel.

53 Palaver, 'Schmitt's Critique of Liberalism," 70. 